\title{
Dwie narracje o Polsce 1981 roku: "Posłanie do ludzi pracy Europy Wschodniej" - Dwie ojczyzny, dwa patriotyzmy
}

Krzysztof Obremski

TEKSTY DRUGIE 2021, NR 3, S. 48-66

DOI: 10.18318/td.2021.3.4 | ORCID: 0000-0001-6164-9207

Bliższa mi jest niebezpieczna wolność niż bezpieczna niewola

motto nielegalnej gazetki szkolnej'

$\mathbf{S}_{\mathrm{n}}^{2}$ zesnaście miesięcy między Sierpniem 1980 a Grudwydarzeń. Po pierwszym roku legalnej działalności NSZZ „Solidarność” nadszedł czas obrad: I Krajowy Zjazd Delegatów. Posłanie do ludzi pracy Europy Wschodniej ${ }^{2}$ splotło się z emocjami oraz ocenami.

Zachodni dziennikarze towarzyszący obradom zjazdu nie mieli wątpliwości, że najważniejszym dokumentem było Posłanie do ludzi pracy Europy Wschodniej, przegłosowane 8 września [1981]. Wyrażano w nim

1 Cyt. za: T.G. Ash Polska rewolucja. Solidarność, przeł. M.K., Polonia, Londyn 1987, s. 217.

2 Podstawowa literatura: M. Kozłowski, Posłanie do ludzi pracy Europy Wschodniej 1981, Media i Rynek, Kalisz 2016.

\section{Krzysztof}

Obremski - prof.

zw. dr hab. (Wydział

Humanistyczny

UMK; Instytut

Literaturoznawstwa,

Katedra Antropologii

Literatury i Nowych

Mediów). Główny

obszar zainteresowań:

to, co wspólne

1. literaturze polskiej

i religii (nie tylko

staropolskie parafrazy

Księgi Psalmów czy

pisma Piotra Skargi);

2. literaturze polskiej

i polityce (szczególnie

nowomowa). Redaktor

książki Marcin Luter

1517-2017 (2019).

Współwydawca

toruńskich wierszy

weselnych i zagadek przełomu XVII/XVIII

stulecia (w druku).

Kontakt: obremski@ umk.pl 
poparcie dla opozycjonistów z państw bloku sowieckiego, podejmujących walkę o prawo tworzenia wolnych związków zawodowych. „Popieramy tych z was, którzy zdecydowali się wejść na trudną drogę walki o wolny ruch związkowy. Wierzymy, że już niedługo wasi i nasi przedstawiciele będą mogli się spotkać celem wymiany związkowych doświadczeń". Posłanie wywołało największą euforię wśród uczestników zjazdu, którzy przyjęli je huraganem braw, na stojąco. Równocześnie jednak wzbudziło wściekłość na Kremlu, a Breżniew nazwał je „bezczelnym wybrykiem” i w telefonicznej rozmowie zwyzywał Kanię, domagając się przyspieszenia wprowadzenia stanu wojennego. ${ }^{3}$

Powstało troiste sprzężenie zwrotne: politycznego kontekstu Posłania, emocji oraz ocen - tak przedstawione przez Jerzego Holzera:

Również czwartego dnia [pierwszej tury, tj. 8.9.1981] doszło do uchwalenia najbardziej kontrowersyjnego dokumentu - Posłania do ludzi pracy Europy Wschodniej. Propozycja wyszła, jak się wydaje, od członka KOR-u [Jana] Lityńskiego, ale znalazła m.in. gorące poparcie [Andrzeja] Gwiazdy, na którego wniosek projekt przyjęto bez uprzedniej dyskusji. Zapewne zaskoczyło to niemal wszystkich czołowych przywódców i ekspertów. Trudno było z projektem polemizować, ponieważ emocjonalnie trafiał do przekonania ogromnej większości delegatów, zaś racje taktyczne nie były przy podniesionej temperaturze w zbyt wysokiej cenie. ${ }^{4}$

Niezależnie od tego, czy faktycznie od każdej zasady są wyjątki, przeczące jej bądź tylko ją podważające, Posłanie może czy nawet powinno jawić się jako zaprzeczenie tych słów autora Krytyki solidarnościowego rozumu: Solidarność - najosobliwsza spośród wszystkich dotychczasowych rewolucji - „nie żywiła też eschatologicznych marzeń w specyficznie rewolucyjnym gatunku"5. Tymczasem Posłanie już od momentu uchwalenia przełamywało horyzonty stanowione ustrojem nazywanym realnym

3 R. Terlecki Solidarność 1980-1981. Polska droga do wolności, Wydawnictwo AA, Kraków 2018, S. 100-101.

4 J. Holzer Solidarność 1980-1981, Wydawnictwo Krąg, Warszawa 1984, S. 180.

5 S. Kowalski Krytyka solidarnościowego rozumu. Studium z socjologii myślenia potocznego, Wydawnictwo PEN, Warszawa 1990, s. 17. 
socjalizmem: w Polsce po lecie 1980 roku między partią komunistyczną a wolnymi związkami zawodowymi trwał zasadniczy konflikt ustrojowy, co "tam i wówczas” (tzn. w Polsce między sierpniem a grudniem) miało znaczenie fundamentalne, a z czasem przynajmniej po części rozstrzygające o „wszędzie” (od Łaby po Cieśninę Beringa) i „zawsze” (tzn. od rewolucji bolszewickiej aż po jesień narodów). Posłanie to było właśnie „eschatologiczne marzenie w specyficznie rewolucyjnym gatunku", ponieważ jakikolwiek niezależny ruch związkowy stanowił realne zagrożenie dla wszystkich państw bloku wschodniego w ich dążeniu do „świetlanej przyszłości”. W Polsce między sierpniem a grudniem obie strony również ideologicznego konfliktu (Polska Rzeczpospolita Ludowa - NSZZ „Solidarność”) zyskiwały coraz mocniejszą świadomość tego, że wręcz stawiają siebie pod ścianą, i jeśli chcą zachować swe analogicznie posplatane polityczne oraz instytucjonalne tożsamości, alternatywa w potocznej polszczyźnie znana jako „wóz albo przewóz” będzie nieunikniona.

Powstała ona [jedna z ważnych, a z perspektywy dzisiejszej może najważniejsza uchwała Zjazdu: Posłanie] i została przegłosowana z porywu serca, wolnościowego romantyzmu. Była wyrazem nadziei delegatów, że „Solidarność" jest pierwszym krokiem, że za nią pójdą inni i będziemy żyć w lepszym świecie. Zarazem w języku realnej polityki przyjęcie Posłania było krokiem radykalnym, przekroczeniem przyjmowanego od Sierpnia samoograniczenia, by podkreślać, że zmiany, które się w Polsce dokonują, mają dotyczyć tylko Polski, są wyrazem polskich specyficznych warunków, a „Solidarność" nie myśli o eksporcie rewolucji. ${ }^{6}$

W ówczesnych realiach geopolitycznych Posłanie stało się „jawnym wyzwaniem rzuconym sowieckiemu imperium"' Tak więc zaledwie jednoroczne maleństwo ${ }^{8}$ z państwa o poważnym znaczeniu geopolitycznym (terytorium PRL to jedyny korytarz nizinny między Bałtykiem a Karpatami) stawiło czoło wówczas wciąż jeszcze niezwyciężonej potędze Związku Radzieckiego i jego

6 A. Friszke Rewolucja Solidarności 1980-1981, Znak Horyzont, Kraków 2014, S. 592-593.

7 Tamże, s. 593.

8 „Obradom Zjazdu towarzyszył plakat ukazujący «Solidarność» jako jednoroczne dziecko, które ma na sobie koszulkę z napisem «Solidarność» i z trudnością utrzymuje się na nogach. W trakcie trwania Zjazdu Służba Bezpieczeństwa (SB) dopuściła się prowokacji i wywieszała nieco inny plakat"; M. Kozłowski Posłanie do ludzi pracy Europy Wschodniej, s. 13-14. 
państw satelickich (dopiero 1982 rok przyniesie kres postępów radzieckiej interwencji wojskowej w Afganistanie). Trafił w sedno w Dziennikach politycznych 1981-1983 Mieczysław Franciszek Rakowski, według którego dokumentu Zjazdu Delegatów nie można „odczytać inaczej niż jako próby nadania wydarzeniom polskim charakteru «nieustającej rewolucji» międzynarodowej, która miała doprowadzić do powstania w krajach socjalistycznych ruchu, dla którego wzorem i przykładem byłaby «Solidarność»" . Nieprzypadkowo 16 września 1981 Biuro Polityczne KC PZPR „potępiło «Solidarność» w oświadczeniu, którego ostrość nie miała dotąd precedensu”, w nim bowiem Posłanie zostało nazwane „obłędną prowokacją wobec sojuszników Polski”"10. Faktycznie: Dawid z satelickiego państwa rzucił komunistycznemu Goliatowi wyzwanie i odtąd ten nie mógł już wątpić, że zagrożenie powstałe w państwie stanowiącym pomost między Związkiem Radzieckim a wojskami w NRD było wręcz śmiertelne, toteż koniecznym warunkiem obrony bloku państw realnego socjalizmu musiało stać się to, że w Polsce „człowiek z betonu” zniewoli „człowieka z żelaza”.Nawet jeśli - jak ówcześnie żartowano - Polska była „najweselszym barakiem w obozie państw socjalistycznych", to przecież w 1981 roku myśl o wolnych związkach zawodowych w pozostałych państwach bloku wschodniego mogła jawić się jako niedorzeczna bądź nawet szalona, ponieważ poprzedzony tzw. polskimi miesiącami akt założycielski Solidarności, jakim stały się strajki 1980 roku, w innych demoludach był czymś z trudem wyobrażalnym. Znamienne: na pytanie o to, dlaczego w państwach realnego socjalizmu strajki są zakazane, propagandowa odpowiedź brzmiała: „w realnym socjalizmie robotnicy rządzą, wobec tego strajkując, strajkowaliby przeciwko sobie"11. W kontekście tak brzmiącego wyjaśnienia należy przywołać Piotra Wierzbickiego i jego Strukturę kłamstwa: „Trzecią [po unieważnieniu języka" $i$, unieważnieniu logiki] fundamentalną operacją myślową przeprowadzoną przez rzeczników realnego socjalizmu w celu wyjęcia spod wszelkiej krytyki własnych kłamstw jest unieważnienie rzeczywistości"12.Znamienny eufemizm: kiedy mniej więcej w połowie sierpnia 1980 roku w partyjno-państwowych mediach w końcu zaczęły pojawiać się pierwsze nie tyle informacje, ile wzmianki o strajkach, przedstawiano je wówczas jako

9 Cyt.za: tamże.

10 J. Holzer Solidarność 1980-1981, S. 271.

11 Za: P. Wierzbicki Struktura kłamstwa, Bellona, Warszawa 2009, s. 27. 
„nieuzasadnione przerwy w pracy”. Dopiero po zmianach wiązanych z 1989 rokiem Postanie z jego myślą o wolnych związkach zawodowych w pozostałych państwach bloku wschodniego mogło stać się prorocze...W kontekście lat 1980-1981, z ich przecież jeszcze bezdyskusyjnie mocarstwowym statusem Związku Radzieckiego, można było stwierdzić, że Posłanie - mówiąc słowami Jacka Kuronia - „To było niepotrzebne drażnienie niedźwiedzia” ${ }^{\text {; }}$; podobnie inni: „nieodpowiedzialne szarpanie białego niedźwiedzia za wąsy” czy „szarpanie tygrysa za ogon"14. Z kolei Andrzej Gwiazda przyznał: „Jest to uchwała idąca prosto z serca, nieco z pominięciem głowy"15. Krytyczna ocena wyraźnie pobrzmiewa w stanowisku Solidarności UAM: „my co prawda jesteśmy nieco podreperowani na duchu i narkotyzujemy się naszą "przebojowością i siłą», ale za to gdy pójdziemy szukać żyranta, odejdziemy z kwitkiem. Będziemy romantycznie dumni, ale goli i bez grosza przy duszy" ${ }^{16}$. Tak werbalizowano napięcie między rewolucyjnymi emocjami a trzeźwą kalkulacją. Również jesienią 1981 roku w paryskiej „Kulturze” pojawił się tekst Jana Józefa Lipskiego Dwie ojczyzny, dwa patriotyzmy. Uwagi o megalomanii narodowej i ksenofobii Polaków ${ }^{17}$. Tekst ów mógł oraz wciąż jeszcze może być czytany jako krytyczna interpretacja Posłania, ponieważ stanowi alternatywną narrację o Polsce 1981 roku. Przy właśnie takiej lekturze niepodobna abstrahować od ówczesnego kontekstu politycznego:

Opublikowanie Dwóch ojczyzn - dwóch patriotyzmów, a zwłaszcza jego szersze rozpowszechnienie po przedruku całości w październikowym numerze paryskiej „Kultury” spowodowało frontalny atak rządowej propagandy. Pretekstem była publikacja fragmentów tego eseju po niemiecku w opiniotwórczym zachodnioniemieckim dzienniku „Frankfurter Allgemeine Zeitung" 13 listopada 1981 r. (trzeba przyznać, że redakcja dokonała nieuzgodnionych z autorem skrótów, zniekształcających jego myśl). Wskutek zmasowanego ataku „Trybuny Ludu” i „Życia Warszawy”

J. Kuroń Gwiezdny czas. „Wiary i winy” dalszy ciagg, Aneks, Londyn 1991, s. 218.

Cyt. za: M. Kozłowski Posłanie do ludzi pracy..., s. 39, 43.

Cyt. za: tamże, s. 63.

Cyt. za: tamże, s. 83.

Autorska pisownia tytułu to: Dwie ojczyzny, dwa patriotyzmy (w: J.J. Lipski Tunika Nessosa. Szkice o literaturze i nacjonalizmie, Wydawnictwo PEN, Warszawa 1992, s. 139-164); pisownia ta wyjątkowo nie jest tu zachowywana w tych cytatach, w których nie przecinek, lecz myślnik oddziela tytułowe człony. 
w milionowym nakładzie upowszechniono nazwisko Lipskiego z przypiętą łatką zdrajcy. ${ }^{18}$

Tak więc obydwie wypowiedzi podmiotów niezależnych od partyjno-państwowej władzy wywoływały analogiczne reakcje propagandowego aparatu: oburzenie splecione z potępieniem.

Posłanie oraz Dwie ojczyzny, dwa patriotyzmy współtworzyły relację paradoksalną: „niezgodnej zgodności”. Obydwa teksty były jawnie antysocjalistyczne, ale werbalizowały dwa odmienne spojrzenia na Polskę 1981 roku, to znaczy wchodziły ze sobą w spór tam, gdzie postrzegały ją w różnych wymiarach. Zarazem wkrótce zostały niejako połączone wprowadzeniem stanu wojennego, który oznaczał może nie ich unieważnienie, ale przynamniej zawieszenie $^{19}$. Ostatecznie od 13 grudnia 1981 dla Solidarności i związanej z nią opozycji demokratycznej pierwszym międzynarodowym wyzwaniem stało się przerwanie „wojennej” blokady informacyjnej (pars pro toto: Małgorzata Niezabitowska i książka W twoim kraju wojna!). Dlaczego Dwie ojczyzny, dwa patriotyzmy mogą być czytane również jako krytyczna interpretacja Posłania i tym samym alternatywna narracja o Polsce 1981 roku? Punktem wyjścia niech będzie tu podstawowa dla teorii komunikacji triada: nadawca - komunikat - odbiorca. N a d a w c a. Obydwa teksty miały ten sam kontekst polityczny: powstały w ostatnich miesiącach między sierpniem a grudniem - to podobieństwo (dzień wprowadzenia stanu wojennego stał się początkiem zawieszenia ich w politycznej próżni) splatało się z licznymi różnicami, wszak opublikowaną przez Niezależną Oficynę Wydawniczą NOWA wypowiedź nieformalnego "prezydenta opozycji” pod względem medialnym

18 Ł. Garbal Prezydent opozycji. Krótka biografia Jana Józefa Lipskiego, IPN, Warszawa 2017, s. 299. Por. J.J. Lipski List otwarty do polskich i niemieckich komentatorów mojej pracy pt. „Dwie ojczyzny, dwa patriotyzmy", w: Pisma polityczne, wybór, opracowanie i objaśnienia Ł. Garbal, Wydawnictwo Krytyki Politycznej, Warszawa 2011, s. 194-198; Odpowiadam na zarzuty, w: tamże, s. 199-210.

19 „Dla współczesnego [tj. W 2012 r.] pokolenia 50-latków wydarzenia lat 1980-81 były przełomowe i pierwszoplanowe; dla części aktywnych na scenie aktorów był to ryt przejścia - zmieniający robotnika czy inteligenta w bojownika. Rozpoczęcie strajku i cały performance z nim związany rozpoczynał sferę graniczną, która pełna była manifestacji odgrywania polskości mimo sztandaru związkowości hasła socjalistyczne były już zużyte przez PZPR i nie dawały poczucia wspólnoty. Stan wojenny zamknął sferę graniczną; internowanie zamknęło rytuał. Było to już, jak się okazuje w narracji, pojmanie czy wzięcie do niewoli bojowników”; J. Wasilewski Opowieści o Polsce. Retoryka narracji, Studio headmade, Warszawa 2012, s. 408-409. Gwoli ścisłości: internowanych oraz aresztowanych działaczy "Solidarności” zastępowali inni, i to oni w poważnym zakresie współtworzyli podziemną "Solidarność". 
trudno porównać z dokumentem ze zjazdu dziesięciomilionowej (formalnie) Solidarności. Rzecz nie tylko w tym, co rozumie się przez nakład i dystrybucję: Posłanie miało zasięg dosłownie masowy (znajdowało poparcie dużej części członków i sympatyków Solidarności), natomiast Dwie ojczyzny, dwa patriotyzmy, nawet jeśli intencjonalnie były skierowane do wszystkich Polek i Polaków (również tych przebywających na emigracji), pozostawały wypowiedzią siłą rzeczy osamotnioną, bo jako narodowy rachunek sumienia były wymierzone w przodków i potomnych odpowiedzialnych za krzywdy i cierpienia sąsiednich narodów. Emocje społeczne były równie ważne jak nakłady i dystrybucja obydwu wypowiedzi. „Emocje rodzą się nie z samych faktów, ale dzięki ich interpretacji i zestawieniom" ${ }^{20}$. Posłanie było tym zjazdowym dokumentem, który przyjęto największą owacją delegatów, a Dwie ojczyzny, dwa patriotyzmy zawczasu zostały skazane na przeważnie wrogą bądź przynajmniej zdystansowaną postawę Polek i Polaków, gdyż mogły być czytane jako spowiedź z dawnych i współczesnych grzechów narodu polskiego. Najkrócej: duma pierwszego w całym bloku wschodnim niezależnego związku zawodowego i z nim zwrotnie sprzężonego społeczeństwa obywatelskiego kontra narodowy wstyd przodków i potomnych z powodu tego wszystkiego, co obciąża ich relacje z Żydami oraz najbliższymi sąsiadami Polski (nawet z Niemcami!).

Ko m u nikat. Już nawet same tytuły obydwu wypowiedzi wskazują na istotną różnicę. Nie chodzi bynajmniej o liczby tytułowych słów, lecz o przeciwne postawy, jakie zawartością obydwu przekazów były kształtowane. Z jednej strony (jak na rocznicowym plakacie związku) chłopczyk z kijkiem w rączce, z drugiej - poniewierany i przez partyjno-rządową propagandę ${ }^{21}$, i przez poważną część Solidarności współtwórca oraz czołowy działacz KOR i KSS KOR (podczas zjazdowych obrad jawnie wręcz poniżony ${ }^{22}$ ). Posłanie

Tamże, s. 10.

„Boje te [z rodzimym nacjonalizmem i antysemityzmem] przysporzyły mi sporo kłopotów, na co mogłaby wskazywać np. bogata literatura o Dwóch ojczyznach, dwóch patriotyzmach w prasie partyjnej i wobec partii dyspozycyjnej. Nie żałuję jednak. Byłem lżony - ale też przedrukowywany, w "Kulturze” i w podziemiu, kilkanaście razy, nie licząc przekładów na obce języki. Wniosłem więc jakiś wkład w tworzenie nowej atmosfery współżycia Polaków z innymi narodami, przede wszystkim Niemcami"; J.J. Lipski Dwie dusze autora, w: tegoż Tunika Nessosa, s. 5. „Pamiętam, na I Zjeździe «Solidarności» (oboje byliśmy delegatami, on z Warszawy, ja z Łodzi) zobaczyłam, że ma na kurtce przypięty Krzyż Walecznych i Krzyż Armii Krajowej. Spytałam więc, czemu ta «wystawa», bo znałam jego skromność. Janek na to smutno powiedział mi, że «prawdziwi Polacy», którzy dość hałaśliwie poczynają sobie na zjeździe, zarzucają jemu, ko- 
było zwięzłe i wyrażało proste przeciwstawienie: „my” (wolny ruch związkowy) kontra „oni” (partyjne władze państw realnego socjalizmu). Natomiast Dwie ojczyzny, dwa patriotyzmy to tekst nie tylko wielekroć dłuższy niż sześciozdaniowy dokument, lecz przede wszystkim rachunek narodowych cierpień „swoich" i „obcych” kwestionujący zero-jedynkową waloryzację dawnych i współczesnych relacji Polaków z Żydami oraz z najbliższymi sąsiadami (za odstąpieniem od biało-czarnej perspektywy postrzegania Niemców przemawiało również osobiste doświadczenie powstańca warszawskiego).

Przekaz zjazdowego dokumentu był prosty i doprawdy jednoznaczny: "tak" dla wolnego ruchu związkowego w Europie Wschodniej oznaczające "nie" dla monopolu partyjnych niby-związków zawodowych (pars pro toto: w Polsce CRZZ). Diametralnie przeciwna była zwerbalizowana przez Lipskiego narodowa spowiedź, w której wyważał te cierpienia „innych”, za które odpowiedzialnością obciążał "swoich" ${ }^{23}$, toteż próżno szukać biało-czarnej perspektywy; zamiast hasła „to oni są wszystkiemu winni"24, bolesna prawda: byliśmy oraz wciąż jeszcze jesteśmy zarówno ofiarami sąsiadów, jak też sprawcami ich cierpień (żadnej tzw. moralności Kalego ${ }^{25}$ ). Posłanie to wyraz

rowcowi, że obca jest mu walka o niepodległość i tzw. miłość ojczyzny. I brat mój chciał w ten sposób pokazać, że jest to nieprawda. Zrobiło mi się bardzo żal, że aż do tego stopnia musiał i chciał się bronić, że został osobiście zraniony, i to przez własnych kolegów z opozycji. Nie wiedziałam wówczas, że przeżyje jeszcze więcej, np. w czasie wyborów czerwcowych w 1989 r."; M. Dmochowska Ktoś to przecież musi zrobić, w: Jan Józef. Spotkania i spojrzenia. Książka o Janie Józefie Lipskim, PIW, Warszawa 1996, s. 17.

23 "Stosunkowo wielu z nas [Polaków] często i chętnie domaga się, aby Ukraińcy - zgodnie ze stanem faktycznym - przyznali, że w latach 1943-1944 na Wołyniu i w Galicji Wschodniej mieliśmy do czynienia z ludobójstwem. Ci sami jednak ludzie są oburzeni, gdy tego samego żądają niektóre środowiska ukraińskie w odniesieniu do ukraińskich ofiar «polskiej samoobrony», względnie «działań odwetowych» podejmowanych na tym terenie przez Armię Krajową i Narodowe Siły Zbrojne. Można powiedzieć, że w tym wypadku narracja polska zderza się z narracją ukraińską w sporze o to, po której stronie było ludobójstwo. Jak się wydaje, to, że mogło ono występować po obu stronach konfliktu, protagonistom nie bardzo przychodzi do głowy"; J. Eisler Narracje o PRL. Jak się opowiada o historii najnowszej?, w: Zapisywanie historii. Literaturoznawstwo i historiografia, red. W. Bolecki, J. Madejski, Fundacja Centrum Międzynarodowych Badań Polonistycznych, IBL PAN, Warszawa 2010, s. 410.

Por. „To oni sq̨ wszystkiemu winni...". Język wrogości w polskim dyskursie publicznym, red. X. Bukowska, M. Markowska, Trio, Collegium Civitas, Warszawa 2013.

"Gdybyśmy nie dotykali tak poważnej kwestii [jak antyżydowski pogrom w Jedwabnem], można by powiedzieć, że ludobójstwo jest wtedy, gdy nam jest wyrządzana krzywda, natomiast kiedy to my ją komuś wyrządziliśmy, sprawa nie jest już taka prosta"; ). Eisler Narracje o PRL, s. 410. 
dumy Solidarności, natomiast Dwie ojczyzny, dwa patriotyzmy to prymarnie wyznanie wstydu Polaka, który dostrzegł i wskazał także winy swego narodu. Te zaś rodacy z trudem darują (vide milenijne „Wybaczamy i prosimy o wybaczenie" Kościoła katolickiego oraz oburzenie wywoływane tymi słowami). Także ostatni element triady, o d b i o r c a , wskazuje na ważną różnicę. Przyjęcie Posłania zarówno w kraju, jak i za granicą było zasadniczo uwarunkowane podziałami politycznymi. Inaczej z Dwiema ojczyznami, dwoma patriotyzmami - te pozostały wypowiedzią o zasięgu w zasadzie głównie krajowym (wyjątkiem Niemcy), a reakcje na nie kształtowały się zgodnie z podziałami narodowymi (my swoi - oni obcy) i politycznymi (tu jakiekolwiek uogólniające twierdzenie byłoby skażone nieuniknionymi uproszczeniami ze względu na wieloraki splot wrogości instytucji partyjno-państwowych, zdystansowanej postawy Kościoła katolickiego wobec laickiego korowca i ważnego masona ${ }^{26}$, wewnętrzne podziały w Solidarności, które sprawiły, że nawet zjazdowe podziękowanie dla korowców stało się przedmiotem jawnej kontrowersji). Ściślej mówiąc: Dwie ojczyzny, dwa patriotyzmy były wypowiedzią o zasięgu zasadniczo elitarnym, gdyż: 1) mogły być tylko indywidualnym wyznaniem narodowych win wobec tych sąsiadów, na których Polacy spoglądali na ogół z nieskrywaną wyższością; 2) w ich integralnej postaci pozostawały dostępne (tzn. czytane) jedynie w tzw. drugim obiegu, a więc w okresie między sierpniem a grudniem zarazem - paradoksalnie - legalnym i nielegalnym. Jeśli Polskę 1981 roku będziemy postrzegać jako czasoprzestrzenne „tu i teraz", dostrzeżemy, w jak przeciwnych kierunkach podążały myśli zwerbalizowane w obu tekstach. I Posłanie, i Dwie ojczyzny, dwa patriotyzmy prymarnie były nakierowane na „teraz”. Związkowcy jakby przeszli do porządku nad swą przedsierpniową przeszłością (to zrozumiałe: tzw. polskie miesiące oraz wolne związki zawodowe dla większości robotników w demoludach byłyby niezrozumiałe) i pozostawali zapatrzeni w przyszłość; Lipski analogicznie był nakierowany na „teraz”, jednak zwracał wzrok również w stronę przeszłości, aby przyszłość mogła stać się jej przezwyciężeniem. Ta różnica spojrzeń na polską historię wydaje się zrozumiała: kiedy zważymy tylko jednoroczną działalność Solidarności, wówczas czymś może nawet oczywistym stanie się, że „bilans zamknięcia” PRL (związki zawodowe jako pas transmisyjny

26 „W tym samym roku [otrzymania trzeciego stopnia wtajemniczenia] Lipski został na blisko dwadzieścia lat (1962-1981) przewodniczącym loży [„Kopernik"] (Czcigodnym Mistrzem). W latach 1981-1986 będzie mówcą, później ponownie przewodniczącym (1986-1988), a następnie sekretarzem (1988-1990)"; Ł. Garbal Prezydent opozycji, s. 169. 
od partii komunistycznej do mas) był jakby po części zawarty w „bilansie otwarcia" samorządnej Rzeczpospolitej. Przeciwnie Lipski: nie mógł tragicznych dziejów relacji Polaków z sąsiadami odsunąć choćby na drugi plan, gdyż w jego postrzeganiu historii przeszłość ciążyła nad teraźniejszością i mogła nadal okaleczać przyszłość.

Zarazem niepodobna abstrahować od różnic generacyjnych: przedstawiciel pokolenia Kolumbów siłą rzeczy odmiennie postrzegał Polskę niż młodsi od niego na ogół o dwie, trzy czy nawet cztery dekady działacze Solidarności. Henryk Samsonowicz, urodzony tylko kilka lat później niż Lipski, uczestnik tajnych kompletów, a zarazem gość Zjazdu, ocenił Posłanie tymi słowami: „Przyznam się szczerze i chcę podkreślić tę osobistą opinię: dla mnie była to najsłuszniejsza w świecie utopia, która nie miała żadnych szans powodzenia, ale była znaczącym gestem, i świadczyła, że będziemy umierać z właściwym okrzykiem" ${ }^{27}$. Takie rozdwojone spojrzenie było uwarunkowane szerszą oraz dalszą perspektywą - sięgającą globalnych doświadczeń drugiej wojny światowej - i dlatego jednak odmienną niż ta kształtowana przede wszystkim przez trzy polskie miesiące: Grudzień 1970, czerwiec 1976 i sierpień 1980. Analiza pentadyczna Kennetha Burke'a ${ }^{28}$ stanowi jedną z możliwości analizy porównawczej Posłania i Dwóch ojczyzn, dwóch patriotyzmów.

Metodą i zarazem narzędziem do analizy stworzonego retorycznie dramatu jest tak zwana pentada - czyli pięć powiązanych ze sobą kategorii [...]. Pozwala ona ukazać, jak mówca narzuca pewien sposób rozumienia rzeczywistości, a przez to przekonuje audytorium do swojego punktu widzenia. ${ }^{29}$

Owe kategorie pentady to: a kt, scena, aktor, sposób działania lub wykonanie, cel ${ }^{30}$. Także poprzez podjęcie analizy pendatycznej

Cyt. za: M. Kozłowski Posłanie do ludzi pracy..., s. 45.

Za: J. Wasilewski Wodzowie kontra gracze. Analiza pentadyczna, w: Instrukcja obsługi tekstów. Metody retoryki, red. J. Wasilewski, A. Nita, Gdańskie Wydawnictwo Psychologiczne, Sopot 2010 , s. $65-75$.

Tamże, s. 68.

„Skupienie się na akcie jest manifestacją zaangażowania się w realizm; koncentrację na scenie można odczytać jako sposób na ograniczenie roli wolnej woli w działaniu i zwrócenie uwagi na determinizm sytuacyjny - ujęcie popularne wśród adwokatów opowiadających o trudnym dzieciństwie i opresyjnym otoczeniu swoich oskarżanych klientów. Emfaza związana z rolą 
można przedstawić „niezgodną zgodność” Postania i Dwóch ojczyzn.„A k t: nazywa to, co się wydarzyło w myślach lub w działaniu; jest odpowiedzią na pytania: co się stało? co się dzieje?"31. Odpowiedzi wydają się proste: nie bacząc na obowiązujące wciąż prawnie zapisy cenzury dwa z trudem porównywalne podmioty - dziesięciomilionowa Solidarność i pojedynczy „prezydent opozycji" - wypowiedziały się antysocjalistycznie. Chociaż i nadawcy (zjazdowi delegaci oraz współtwórca i działacz KOR), i adresaci obydwu przekazów (tytułowi „ludzie pracy Europy Wschodniej”, zawężeni jednak do „robotników”, oraz Polacy ${ }^{32}$ ) byli, można powiedzieć, w poważnym zakresie rozdzielni, to przecież zostali swoiście połączeni atakami partii mieniącej się przewodnią siłą narodu. Dopiero w kontekście późniejszej o dekadę „jesieni narodów" obydwie wypowiedzi zostaną jakby reaktywowane łańcuchem przełomowych wydarzeń, by wieść życie po życiu: od przetrwania Solidarności i opozycji demokratycznej po 13 grudnia 1981 (dwakroć Contra spem spero?) do rozpadu bloku państw zwących się socjalistycznymi; od narodowego rachunku sumienia osamotnionego autora Dwóch ojczyzn, dwóch patriotyzmów do pojednania Polaków z ich niemieckimi sąsiadami (symboliczne spotkanie premiera Tadeusza Mazowieckiego i kanclerza Helmuta Kohla w Krokowej33). „S c e n a: nazywa miejsce, w którym się ów akt dokonał, albo sytuacje, w jakiej się wydarza; jest odpowiedzią na pytania: gdzie to ma miejsce? gdzie to się wydarza? na jakim tle mamy to widzieć?"34. Najłatwiejsza będzie odpowiedź na ostatnie pytanie. Kontekst krajowy to państwo realnego socjalizmu zwane Polską Ludową

aktora podkreśla tożsamość, wspólnotę i wynikający z niej obowiązek działania. Ciążenie ku rozważaniu wykonania może świadczyć o pragmatycznym podejściu, natomiast wystawianie na pierwszy plan celu może zdradzać inklinacje ku mistycyzmowi"; tamże, s. 69, podkr. aut.

Tamże, s. 68.

Oczywiście te dwa podziały są skażone uproszczeniami, ponieważ należy wyróżnić np. adresata pierwszorzędnego (robotnicy Europy Wschodniej), drugorzędnego (członkowie "Solidarności") i trzeciorzędnego (partie komunistyczne państw bloku wschodniego). Co więcej, można również przyjąć, że robotnicy Europy Wschodniej mogli być postrzegani jedynie jako adresat powierzchniowy, a komuniści - jako adresat głębinowy.

33 "[...] sądzę, że problemy poruszone w Dwóch ojczyznach - dwóch patriotyzmach winny stać się przedmiotem szerokiej i poważnej dyskusji nie tylko w aspekcie stosunków polsko-niemieckich, lecz również polsko-litewskich, polsko-białoruskich, polsko-ukraińskich, polsko-czeskich, polsko-rosyjskich i polsko-żydowskich. Mimo że odpowiednie [tzn. inne niż poświęcony Niemcom - K.O.] rozdziały mojej książeczki nie zostały zaatakowane - ufam, że zasłużyły na równie gwałtowne i nierzetelne napaści jak rozdział polsko-niemiecki"; J.J. Lipski List otwarty..., s. 197-198.

34 J. Wasilewski Wodzowie kontra gracze, s. 68. 
i rządząca nią Polska Zjednoczona Partia Robotnicza, ale ówcześnie można było mówić o nieformalnym stanie dwuwładzy PZPR i Solidarności. Kontekst międzynarodowy: Posłanie jako świadectwo „wspólnoty naszych [robotniczych] losów" i tym samym otwarte oraz prowokacyjne spojrzenie w twarz partiom komunistycznym bloku państw zwanych socjalistycznymi; Dwie ojczyzny, dwa patriotyzmy a sąsiedzi Polski oraz powojenni emigranci ${ }^{35}$. Obydwie wypowiedzi wyostrzały konflikty przez ich otwarte wysłowienie (które przez dziesięciolecia poważnie ograniczała działalność cenzury). Obie współbrzmiały w tym, że kształtowały postawę wrogą ksenofobii.„A k t o r: określa rolę tego, kto jest zaangażowany w działanie; to odpowiedź na pytania: kto ów akt zrobił? kto jest odpowiedzialny za to, że się wydarzył?"36. W tym punkcie analiza pentadyczna ujawnia zasadniczą różnicę między obydwoma podmiotami, tym bowiem jest przeciwieństwo między masowym ruchem społecznym NSZZ „Solidarność” i mandatami demokratycznie wyłonionych delegatów a po części zawieszonym w społecznej próżni „prezydentem opozycji”, który wraz z KOR-em został przez zjazd wręcz sponiewierany ${ }^{37}$. To przeciwieństwo poniekąd przesłaniały pryncypialne głosy krytyki ze strony partyjno-rządowej propagandy. Zarazem pytanie „kto jest odpowiedzialny za to, że się [akt] wydarzył?" wiązało się z innym: jakie będą jego następstwa ${ }^{\mathbf{3} ?}$ ? Odpowiedzi brzmią po trzykroć odmiennie - zależnie od kontekstu historycznego - od tego, czy dotyczą okresu przed wprowadzeniem stanu wojennego, po jego wprowadzeniu czy po wyborach z 4 czerwca 1989 roku.

„Sposób działania lub wykonanie: nazywa środki, sposobylub narzędzia, którymi aktor się posługuje do wykonania tego, co się wydarzyło, co ma się wydarzyć; odpowiada na pytanie: co trzeba zrobić w danej sytuacji, mając daną tożsamość, która wyznacza dany cel?" ${ }^{39}$. Posłanie - wydarzenie bez precedensu - poszło w Polskę i w świat. Dwie ojczyzny, dwa patriotyzmy były ważne zasadniczo tylko dla opozycji demokratycznej oraz niemieckiego sąsiada (wydaje się, że wypowiedzi wschodnich sąsiadów Polski nie tyle

Por. J.J. Lipski Odpowiadam na zarzuty, s. 199-210.

J. Wasilewski Wodzowie kontra gracze, s. 68.

Szerzej: Ł. Garbal Prezydent opozycji, s. 286-287.

„Mimo że pentada zaproponowana przez Burke'a nie odróżnia celu skierowanego na przyszłość od powodu zakorzenionego w przeszłości (istotnych dla narracyjnego ujęcia), ważne jest, co podkreśla autor, że ukazuje ona ludzkie działanie jako ruch intencjonalny”; J. Wasilewski Wodzowie kontra gracze, s. 69.

J. Wasilewski Wodzowie kontra gracze, s. 68-69. 
zostały zastąpione, ile przesłonięte głosami polskich emigrantów). „Co trzeba zrobić w danej sytuacji, mając daną tożsamość, która wyznacza dany cel?". I zjazdowi, i autorowi Dwóch ojczyzn przyszło czekać na rozwój dramatycznie zawikłanej sytuacji w Polsce, któremu towarzyszyło pytanie „wejdą czy nie wejdą?". Dynamika wydarzeń jesiennych miesięcy 1981 roku sprawiła, że obydwie wypowiedzi miały coś z meteoru czy fajerwerku: rozbłysły, aby wraz $\mathrm{z}$ wprowadzeniem stanu wojennego przygasnąć i dopiero po kil ku latach powrócić, aby wieść swe życie po życiu.

Ta kategoria pentady - sposób działania lub wykonanie - wiąże się z nieuniknioną problematyką intertekstualności, która już sama w sobie jest materią sporną. Zarazem o relacjach intertekstualnych między Postaniem a Dwiema ojczyznami o tyle trudno mówić, że nawet jeśli najogólniejsza geneza obydwu wypowiedzi wiąże się z jednym kontekstem historycznym (Polska 1981 roku), to przecież genetycznych związków dostrzec nie można - obydwie de facto pojawiły się jednocześnie w odmiennych formach gatunkowych oraz medialnych („Nośnik jest przekazem”). Oba teksty jako wiązki cech gatunkowych współtworzą wręcz znikomą wspólnotę, gdyż posłanie i esej to wypowiedzi gatunkowo pod wieloma względami odmienne: począwszy od objętości, przez poziomy sztuki wysłowienia, aż po tryby perswazji: związkowa „dobra nowina” kontra miniwykład historii Polski (tzn. przede wszystkim jej relacji sąsiedzkich) jako narodowy rachunek sumienia. Toteż relacje intertekstualne między Posłaniem a Dwiema ojczyznami nie są płaszczyzną nawiązań między samymi tekstami, lecz stanowią jedynie umiarkowanie ważną przesłankę ich politycznych funkcji.

„C e l: określa implikowany lub ustanowiony powód działania w akcie; odpowiada na pytanie: po co?"40. Najkrótsza odpowiedź obydwu autorskich i tym samym aktorskich podmiotów mogłaby zostać zawarta w tych słowach: Contra spem spero! To również znaczy: zawierzywszy temu, co przyniesie przyszłość, wypowiedzieć swoje myśli i emocje wbrew ograniczeniom cenzury (także autocenzury?) oraz przeszedłszy do porządku nad trzeźwą kalkulacją argumentów (ówczesne manewry armii Układu Warszawskiego dostatecznie unaoczniały satelicki status PRL), odważnie podjąć trudne i poniekąd karkołomne wyzwania: kształtować wspólnotę ludzi pracy w całym bloku wschodnim oraz przeprowadzić rachunek sumienia narodu w jego niekiedy tragicznych relacjach ze wszystkimi sąsiadami w przeszłości. Dopiero to wszystko, co z czasem będzie znane jako „jesień narodów”, stanie się 
dalekosiężnym sensem inicjatyw - zdawałoby się - skazanych na klęskę. Materią społecznej empirii jest odróżnianie nadziei od iluzji - to przyszłość rozstrzyga o tym, co wiarą, a co mrzonką. Znamiennie zabrzmi odpowiedź na pytanie o to, czego nie zbadamy za pomocą pentady: „przede wszystkim ewentualnej skuteczności mowy" $i$,jej dostosowania do audytorium" ${ }^{\prime 1}$. (Takie jej ograniczenia powinny przynajmniej częściowo przezwyciężać te części niniejszej publikacji, które poprzedzają analizę pentadyczną oraz następują po niej).Ogólne pytanie brzmi: „dlaczego pewne wydarzenia, które w swoim czasie wydają się istotne, nie wpisują się w mityczną narrację, nie są eksponowane w pamięci zbiorowej i po pewnym czasie zanikają"? ${ }^{42}$. Ile takich wydarzeń, tyleż odpowiedzi. Postanie? Wydarzenia jesieni narodów 1989 roku pozwoliły robotnikom Europy Wschodniej poniechać myśli o wolnych związkach zawodowych jako wcześniej jedynym antidotum na realny socjalizm, gdyż ten będzie odchodzić w przeszłość i odtąd (przynajmniej w Europie) wieść już tylko reliktowe życie po życiu.- Dwie ojczyzny, dwa patriotyzmy? Jesień narodów wiązała się z rozpadem „imperium zła”, zarazem Unia Europejska dodatkowo połączyła Polskę z jej zachodnimi i południowymi sąsiadami, co niejako przeważyło nad wciąż z pewnością trudnymi relacjami III RP z Litwą, Białorusią, Ukrainą, Czechami i Rosją (jedynie bodaj Słowacja nie stanowi poważniejszego problemu polityki zagranicznej).Zarazem niepodobna abstrahować od postaci autora Dwóch ojczyzn, dwóch patriotyzmów: laicki KOR ${ }^{43}$ i wolnomularska loża „Kopernik” dla Kościoła katolickiego, który niegdyś

Tamże, s. 74 .

J. Wasilewski Opowieści o Polsce, s. 465.

"[...] symbolika Polskiego Zgromadzenia Narodowego [tzn. Zjazdu „Solidarności” - K.O.] była wspaniała. Od momentu, kiedy elektroniczna tablica do ogłaszania wyników zajaśniała znakiem krzyża i słowami Polonia semper fidelis, kiedy Wałęsa wstał i raz jeszcze zaintonował Jeszcze Polska nie zginęła, a potem Boże, coś Polskę... - bezduszna zazwyczaj hala Olivii zapełniła się duchami męczenników narodowych. [...] Drugiego dnia sala zerwała się z aplauzem, kiedy powoli, o kulach, wszedł na podium mężczyzna w średnim wieku. Był to przywódca robotników poznańskich z czerwca 1956 roku. «Ludzie oddali życie za to, by taki zjazd mógł się odbyć» - powiedział”; T.G. Ash Polska rewolucja. Solidarność, s. 135. „W wyjściowej narracji o proteście robotniczym [Radom 1976 r.] i rozpoczęciu współpracy między robotnikami i inteligencją, która jest opowieścią KOR-owską, «Solidarność» lat 90. zaczęła eksponować zupełnie nowe wypadki związane z ofiarami wśród duchownych. [...] Romantyczny rytuał przechowywany przez Kościół przez lata zaborów i okupacji narzucił narrację kościelną o poświęcających się męczennikach, co jest paralelne do głównej opowieści Kościoła, więc łatwe w rytualnej obsłudze. [...] Odłączenie laickiego KOR od wydarzeń radomskich ustawiło nową ramę dla tamtych wydarzeń"; J. Wasilewski Wodzowie kontra gracze, s. 457-458. 
zawładnął i wciąż w poważnym zakresie włada polską pamięcią zbiorową, to okoliczności wręcz obciążające.Tak więc Posłanie oraz Dwie ojczyzny, dwa patriotyzmy współbrzmiały „niezgodnie zgodnie”. Takie też pozostaje ich „życie po życiu": chociaż wprowadzenie stanu wojennego było jakby zatrzaśnięciem trumny nad obydwiema wypowiedziami, to przecież po upływie czterech dziesięcioleci odmiennych aktualności ich przesłań zakwestionować niepodobna. Mimo wszystko prościej (ale nie prosto czy tym bardziej bezspornie!) rzecz się ma z Posłaniem, o czym przekonuje choćby rzut oka na adresatów: „robotnicy Albanii, Bułgarii, Czechosłowacji, Niemieckiej Republiki Demokratycznej, Rumunii, Węgier i wszystkich narodów Związku Radzieckiego". Otóż dziś spośród tych państw trzech (Czechosłowacji, NRD oraz Związku Radzieckiego) próżno szukać na mapie, a zarazem z najwyższym trudem można porównywać np. Albanię z Litwą, Łotwą czy Estonią (chociaż nie wolno zapomnieć o tym dwugłosie: „świadectwem bystrości umysłu jest dostrzeganie podobieństwa między rzeczami nawet bardzo odległymi" ${ }^{44}$ [Arystoteles] $\mathrm{i}$ „cechą charakterystyczną wyobraźni jest przeskakiwanie [transilire] tego, co znajduje się pod nogami, a łączenie elementów odległych"45 [Cyceron]). Zarazem nadzieja zjazdowych delegatów na to, że ,już niedługo wasi i nasi przedstawiciele będą się mogli spotkać celem wymiany związkowych doświadczeń", przynajmniej połowicznie pozostała iluzoryczna: nawet jeśli "niedługo" z czasem będzie znaczyć „niecała dekada” (1981-1989), to przecież jedynie w Polsce „wolny ruch związkowy” był jedną z najważniejszych determinant upadku socjalistycznego państwa. Co więcej i niejako tym samym co gorsza dla Posłania: Magdalenka, okrągły stół i wybory z 4 czerwca 1989 roku nie były tak widowiskowe, jak przełamywanie granicznych szlabanów oraz przede wszystkim zburzenie muru berlińskiego, a jednocześnie w innych państwach bloku socjalistycznego wolny ruch związkowy pozostał inicjatywą pojedynczych działaczy. W dodatku od lat w samej Polsce niektórzy mówią o dwóch Solidarnościach: pierwszej oraz drugiej.W kontekście pytania o aktualność przesłań Dwie ojczyzny, dwa patriotyzmy stanowią znacząco trudniejsze wyzwanie, i to nie tylko z powodu przełomowych zmian geopolitycznych. Niezmienne pozostaje to, że Polska 1981 i 2021 roku istnieje w tych samych granicach i że podtytuł Uwagi o megalomanii narodowej i ksenofobii Polaków jeszcze dziś w uszach wielu Polaków wciąż może brzmieć... prowokacyjnie, to znaczy oskarżycielsko i zarazem niczym pomówienie. Ostatecznie 
w nieskończoność można się spierać zarówno o to, gdzie kończy się zacna duma narodowa, a zaczyna naganna megalomania, jak i o to, kiedy krytyczne oceny innych narodów stają się ksenofobiczne.

Posłanie było przekazem zaadresowanym „w świat”, natomiast Dwie ojczyzny musiały bądź też przynajmniej powinny być czytane w skali „jednostkowej", gdyż miały stanowić wyzwanie dla sumień, a te były i wciąż są raczej indywidualne (np. oceny oraz emocje związane z III Rzeszą mogą być odmienne niż te wywoływane przez Związek Radziecki - wrzucenie do jednego worka obozów koncentracyjnych oraz archipelagu gułag i połączenie czy też zwieńczenie ich terminem „totalitaryzm” to przedsięwzięcie bardziej badawcze niż osobiste (znamienne, że faszystowska oraz komunistyczna nowomowa bywają bądź łączone, bądź przeciwstawiane). Posłanie pozostało aktem bez precedensu w dziejach Polski (przy nim nawet spotkania czechosłowackich i polskich opozycjonistów w Sudetach oraz Tatrach to wydarzenia bardziej symboliczne niż realnie społeczne). Natomiast Dwie ojczyzny, dwa patriotyzmy były poniekąd powrotem do 1965 roku i orędzia biskupów polskich do niemieckich: „udzielamy wybaczenia i prosimy o nie" - to znaczy charakteryzowała je ta sama postawa poniechania zero-jedynkowego spojrzenia na "swoich” i „obcych”, choć nieporównywalnie szersza, gdyż obejmująca wszystkie sąsiednie narody wokół Polski oraz Żydów.

Z jednej strony cztery dekady od 1981 roku to okres zasadniczych zmian w Polsce i w Europie (o świecie nie wspominając), z drugiej - problemy pozostają niezmienne bądź przynajmniej podobne:

- Niemcy: nawet jeśli „wysiedlanie ludzi z ich domów” (tzn. Niemców z Ziem Zachodnich i Odzyskanych) współcześnie trudno czy nawet wręcz niepodobna uważać za pierwszoplanową przewinę Polaków po drugiej wojnie światowej (Aleksandrów i Nieszawa w 1945 roku $^{46}$; wśród ofiar matka

46 "Na terenie powiatu nieszawskiego, gdzie w pierwszych miesiącach $1945 \mathrm{r}$. przebywało ponad 4000 Niemców, w kilku miejscowościach powiatu doszło do masowych lub pojedynczych morderstw na ludności niemieckiej. Pierwszym z tych ośrodków był Aleksandrów, gdzie zamordowano najliczniejszą grupę Niemców, maksymalne szacunki sięgają nawet 100 ofiar. Drugim miejscem mordu na Niemcach była Nieszawa. [...] Sprawa mordu na nieszawskich Niemcach nie jest jeszcze, mimo zakończenia śledztwa przez Instytut Pamięci Narodowej, do końca wyjaśniona, jak inne tego typu operacje [milicjantów], w tym mord w Aleksandrowie"; M. Golon Dzieje Nieszawy, t. 2 1945-1990, Urząd Miasta Nieszawy, Towarzystwo Naukowe w Toruniu, Toruń 2005, s. 12-15. 
z czworgiem dzieci - najmłodsze miało trzy lata ${ }^{47}$ ), to przecież szeroka współpraca gospodarcza po obu stronach polsko-niemieckiej granicy przesłoniła problematykę rewindykacji i reparacji (vide dziś wyciszona działalność posła Andrzeja Mularczyka).

- Rosja: już nie ma Związku Radzieckiego, negatywne emocje wobec państwa rosyjskiego są motywowane także nową okolicznością: katastrofą smoleńską i wciąż przedłużającym się oczekiwaniem na finalny raport tzw. komisji Antoniego Macierewicza.

- Litwa, Białoruś, Ukraina: te trzy radzieckie republiki to po 1989 roku niepodległe państwa, ale relacje z nimi dalej pozostają trudne bądź przynajmniej szorstkie (istotne novum: ukraińscy imigranci).

- Czechosłowacja: to już dwa samoistne państwa; czworokąt Warszawa - Praga - Bratysława - Budapeszt jest jedynie wspomnieniem poniechanej inicjatywy; dla III RP wyłącznie Słowacja pozostaje „bezproblemowym” państwem sąsiedzkim.

- Po czterech dekadach od 1981 roku Żydzi i polski antysemityzm niezmiennie stanowią wciąż żywotną część Uwag o megalomanii narodowej i ksenofobii Polaków.

Lech Kaczyński jako pierwszy prezydent III RP modlił się w synagodze podczas Chanuki i w oknach Pałacu Prezydenckiego nakazał stawiać świece (wcześniej jako minister sprawiedliwości na prośbę Żydów zakończył ekshumacje w Jedwabnem, co - jak również fakt, że wspierał budowę Muzeum Historii Żydów Polskich - skłoniło o.Tadeusza Rydzyka do nazwania go oszustem). Rzecz przed 1989 rokiem po prostu niewyobrażalna: 10 maja 2018 roku prezydent Donald Trump podpisał przyjętą przez Kongres i Senat Ustawę 447, która umożliwia Stanom Zjednoczonym wywieranie dyplomatycznego nacisku na Polskę w sprawach bezspadkowego mienia ofiar Holocaustu. Coś takiego w 1981 roku nikomu nie przyszłoby do głowy... Zarazem Jan Józef Lipski jeszcze mógł twierdzić, że „szmalcownictwo" było jedynie marginalne (vide publikacje Jana Grabowskiego).

Dwie ojczyzny, dwa patriotyzmy to wypowiedź zasadniczo zakorzeniona także w realiach Polski 1981 roku, co cztery dekady później rozstrzyga o zakresie dezaktualizacji przesłania „prezydenta polskiej opozycji”. Poprzestańmy na dwóch przykładach: 1) Główny Urząd Kontroli Prasy, Publikacji i Widowisk kontra Interneti„mediokracja” - Literacka Nagroda

47 J. Morawiecki Dąb piramidalny: w Nieszawie stanie pomnik niemieckich sq̨siadów pomordowanych w 1945 r. przez Polaków, "Tygodnik Powszechny” 2004 nr 34, s. 4. 
Nobla dla Czesława Miłosza nie zmieniła stanowiska władz PRL wobec jego dalej zasadniczo drugoobiegowego statusu; ta sama nagroda dla Olgi Tokarczuk wywołała podobnie zdystansowaną czy nawet wrogą postawę, ale w reakcji na światowy sukces polskiej literatury rynek wydawniczy nie przejął się słowami wicepremiera i ministra Piotra Glińskiego; 2( Konrad Adenauer w krzyżackim płaszczu kontra Borussia Dortmund i polscy „trzej muszkieterowie" niemieckiej ligi piłki nożnej - Kuba Błaszczykowski, Robert Lewandowski, Łukasz Piszczek.

W 1981 roku według „prezydenta polskiej opozycji” najpoważniejszym zagrożeniem dla Polski w Europie był - termin tu powtórzony dosłownie sowietyzm. Czterdzieści lat później należy dostrzec fundamentalną zmianę: to suweren w kolejnych aktach wyborczych rozstrzyga o usytuowaniu Polski w Europie, na jej skraju bądź poza nią. Chodzi oczywiście nie o położenie geograficzne, lecz o mechanizmy polityczne oraz wartości i posplatane $\mathrm{z}$ nimi emocje.

Paradoksalnie, prezydencka kampania wyborcza z 2020 roku wycinkowo odsłoniła i aktualność, i anachronizm Uwag o megalomanii narodowej $i$ ksenofobii Polaków. Mianowicie osoby nieheteronormatywne jakby zastąpiły Żydów w ich funkcji (poniekąd dyżurnego?) wroga wewnętrznego. Sprzeciw wobec jednych i drugich ma podobne uzasadnienie - religijne. Żydzi ukrzyżowali Jezusa Chrystusa i tym samym od wieków niezmiennie uderzają w katolicką tożsamość narodową Polek i Polaków - osoby niehetronormatywne, z ich współczesną ofensywą „,ideologii gender”, niszczą tradycyjną rodzinę polską, która wszak była, jest i będzie fundamentem Polski apriorycznie katolickiej (jedno z haseł współczesnej mowy nienawiści brzmi: „Ręka podniesiona na Kościół to ręka podniesiona na Polskę"48). Jednym i drugim, Żydom oraz osobom nieheteronormatywnym, przypisuje się tę samą funkcję: "To oni są wszystkiemu winni" ${ }^{49}$ - przy tym w stanie zagrożenia Ojczyzny milczenie byłoby zbrodnią stanu. Zarazem bezrefleksyjnie przechodzi się do porządku nad tym, że do hitlerowskich obozów koncentracyjnych wywożono zarówno Żydów, jak i osoby nieheteronormatywne. Obie grupy mogą być postrzegane jako przykłady działania tego samego mechanizmu społecznego:Jak „inny” staje się "obcym”

48 P. Niemczyk Pogarda. Dlaczego rośnie liczba przestępstw z nienawiści w Polsce, Społeczny Instytut Wydawniczy Znak, Kraków 2019, s. 237-253.

49 "To oni sq wszystkiemu winni..."|ęzyk wrogości w polskim dyskursie publicznym, red. X. Bukowska, B. Markowska, Collegium Civitas, Wydawnictwo Trio, Warszawa 2013. 
albo kiedy różnica staje się piętne $\mathrm{m}^{50}$.Znamienniebrzmi jedno z haseł polskiej mowy nienawiści: „Pedały do gazu, a lesby do leczenia”.

\section{Abstract}

\section{Krzysztof Obremski}

NICOLAUS COPERNICUS UNIVERSITY (TORUŃ)

Two Narratives about Poland of Autumn 1981:"A Message to the Working People of Eastern Europe" - Two Homelands, Two Patriotisms

Obremski offers a comparative analysis of "Posłania do ludzi pracy Europy Wschodniej" [A Message to the Working People of Eastern Europe], formulated during the Solidarity Trade Union's First National Congress of Delegates, and Jan Józef Lipski's essay Dwie ojczyzny, dwa patriotyzmy [Two Homelands, Two Patriotisms]. Both speaking subjects are independent of state and party power, and their messages both help create an incompatible compatibility: they are openly anti-socialist but project two different perspectives on Poland in the year 1981. Although not opposed to each other, these two perspectives present Poland in different dimensions.

\section{Keywords}

NSZZ "Solidarność", Solidarity, Jan Józef Lipski, narratives about Poland, Kenneth Burke's pentad

50 M. Sałkowska /ak „inny” staje się „obcym”, albo kiedy różnica staje się piętnem”, w: „To oni sq wszystkiemu winni...", s. 91-115. 